\title{
Keefektifan Model Discovery Learning dengan Brainstorming terhadap Kemampuan Berpikir Kritis Peserta Didik
}

\author{
Nurhasanah $^{1}$, Djukri $^{1}$ \\ ${ }^{1}$ Pendidikan Biologi-Universitas Negeri Yogyakarta
}

\begin{tabular}{l} 
INFO ARTIKEL \\
\hline Riwayat Artikel: \\
Diterima: $23-04-2019$ \\
Disetujui: 24-05-2019 \\
\hline
\end{tabular}

Kata kunci:

effectiveness;

discovery learning;

brainstorming;

critical thinking skills;

keefektifan;

kemampuan berpikir kritis

ABSTRAK

\begin{abstract}
This reseach was aimed to determine the effectiveness of the Discovery Learning model with Brainstorming on students' critical thinking skills. This research is a quasi-experiment with a non-equivalent pretest-posttest control group design. Data analysis used t-test and continued with an analysis of the $\mathrm{N}$-gain value. The results showed that there was a significant difference between the experiment class and the control class with a significance value of $0,001 \leq 0,05$. N-gain values in the experiment class and control class were 0.53 and 0.30 , this means that the improvement of students' critical thinking skills in the experimental class is better than the control class.
\end{abstract}

\begin{abstract}
Abstrak: Penelitian ini bertujuan untuk mengetahui keefektifan model Discovery Learning dengan Brainstorming terhadap kemampuan berpikir kritis peserta didik. Penelitian ini adalah penelitian quasi-eksperimen dengan desain non-equivalent pretestposttest control group design. Analisis data menggunakan uji independent t-test dan dilanjutkan dengan analisis nilai $\mathrm{N}$-gain. Hasil penelitian menunjukkan adanya perbedaan yang signifikan antara kelas eksperimen dan kelas kontrol yaitu dengan nilai signifikansi $0,001 \leq 0,05$. Nilai $N$-gain pada kelas eksperimen dan kelas kontrol masing-masing 0,53 dan 0,30 , ini berarti peningkatan kemampuan berpikir kritis peserta didik pada kelas eksperimen lebih baik dibandingkan dengan kelas kontrol.
\end{abstract}

\author{
Alamat Korespondensi: \\ Nurhasanah \\ Pendidikan Biologi \\ Universitas Negeri Yogyakarta \\ Jalan Colombo No.1 Kec. Depok, Kab. Sleman, Daerah Istimewa Yogyakarta \\ E-mail: nurhasanah.2017@student.uny.ac.id
}

Abad 21 ditandai dengan pesatnya perkembangan ilmu sains dan teknologi. Oeh sebab itu, diperlukan suatu proses pembelajaran yang dapat membuat peserta didik untuk tertarik terhadap ilmu sains dan teknologi. Pada era globalisasi saat ini peserta didik dituntut untuk menyiapkan berbagai keterampilan seperti kemampuan berpikir kritis, berpikir kreatif, dan pemecahan masalah agar dapat diterapkan dalam kehidupan sehari-hari. Penggunaan metode investigasi atau penyelidikan merupakan salah satu ciri khusus pada pembelajaran sains dan biologi yang dapat memberikan solusi dalam suatu pembelajaran melalui kegiatan inkuiri sehingga dapat memberikan kontribusi pada perkembangan kemampuan menganalisis dan berpikir kritis.

Berpikir kritis merupakan kemampuan yang melibatkan penalaran logis, menafsirkan, menganalisis dan mengevaluasi informasi untuk memungkinkan peserta didik mengambil keputusan yang andal dan valid dalam menyelesaikan masalah baik dalam pembelajaran maupun dalam kehidupan sehari-hari (Chukwuyenum, 2013). Seseorang yang berpikir kritis akan mengajukan suatu pertanyaan dan masalah yang penting, kemudian merumuskannya dengan jelas, mengumpulkan dan menilai informasi dengan relevan, berpikiran terbuka, menggunakan ide-ide abstrak, dan berkomunikasi secara aktif dengan orang lain (Duron, Limbach, \& Waugh, 2006). Selanjutnya, Zetriuslita, Ariawan, \& Nufus (2016) menyatakan peserta didik yang dapat berpikir kritis akan dapat memahami masalahnya dengan baik, kemudian membuat rencana untuk memecahkan masalah tersebut, dan membuat penyelesaian alternatif secara lebih praktis. Menurut Amri \& Ahmadi (2010) agar setiap individu dapat memperoleh, memilih, dan mengolah informasi dengan baik dan bijak maka diperlukan keterampilan berpikir kritis. Namun, pada kenyataannya kemampuan berpikir kritis peserta didik masih belum sepenuhnya dapat dikembangkan.

Berdasarkan hasil observasi dan wawancara yang dilakukan di sekolah ditemukan bahwa guru lebih berfokus pada penguasaan materi dan jarang menggunakan model pembelajaran yang menuntut peserta didik untuk melakukan pengamatan secara langsung melalui kegiatan penyelidikan, hal tersebut menyebabkan kurang dibekalinya peserta didik dalam memecahkan suatu persoalan sehingga kemampuan berpikir kritis peserta didik rendah. Untuk mengatasi hal tersebut, guru harus melakukan suatu inovasi dalam proses pembelajaran sehingga dapat mengembangkan kemampuan berpikir kritis peserta didik. Salah satu model pembelajaran yang dapat digunakan adalah model Discovery Learning. 
Bruner (1997) menyatakan, model Discovery Learning adalah model yang digunakan untuk mencapai dan menemukan jawaban mereka sendiri terhadap masalah yang diajukan melalui serangkaian kegiatan pembelajaran yang menekankan pada proses berpikir kritis dan analisis. Discovery Learning dapat membantu guru dalam meningkatkan kemampuan berpikir kritis (Pertiwi, Marpaung, \& Yolida, 2015: Ballew, 1967). Selanjutnya (Balım, 2009) berpendapat bahwa Discovery Learning merupakan suatu metode yang mendorong peserta didik sampai pada kesimpulan berdasarkan kegiatan dan pengamatan yang mereka lakukan sendiri. Pada Discovery Learning peserta didik membangun pengetahuannya berdasarkan informasi baru yang mereka terima dan data dikumpulkan oleh mereka sendiri dalam lingkungan belajar yang eksploratif (De Jong \& Van Joolingen, 1998: Njoo, 1994). Menurut Nugrahaeni, Redhana, \& Kartawan (2017) pembelajaran dengan Discovery Learning atau penemuan dapat membuat peserta didik memperoleh pengetahuan yang bertahan lama atau lebih mudah untuk diingat, dan hasil belajar penemuan mempunyai efek transfer yang lebih baik dan secara menyeluruh, peserta didik dapat meningkatkan kemampuan penalaran dan keterampilan berpikir kritis melalui belajar penemuan. Peserta didik juga dapat belajar berpikir analisis dan memecahkan sendiri masalah yang mereka hadapi melalui belajar penemuan. Kebiasaan ini dapat diaplikasikan dalam kehidupan sehari-hari (Hosnan, 2014).

Sasaran utama dari model Discovery Learning adalah peserta didik secara maksimal dapat terlibat dalam kegiatan pembelajaran dan dapat mengembangkan kepercayaan diri tentang apa yang ditemukan saat proses pembelajaran (Martaida, Bukit, \& Ginting, 2017). Dalam proses pembelajaran dengan discovery learning, guru mendorong peserta didik untuk memiliki pengalaman serta melakukan percobaan dan peserta didik didorong untuk secara aktif terlibat dalam proses pembelajaran (Hosnan, 2014). Peserta didik dituntut untuk membangun pengetahuan secara aktif tidak lagi hanya menerima pengetahuan secara pasif dari guru. Peran peserta didik harus lebih ditingkatkan dalam proses pembelajaran, ide-ide yang dimiliki oleh setiap peserta didik hendaknya dapat dimunculkan oleh guru. Upaya yang dilakukan untuk mendukung berlangsungnya Discovery Learning yaitu dengan menggunakan metode pembelajaran yang dapat membuat peserta didik mengeluarkan ide dan gagasan sebanyak-banyaknya. Metode pembelajaran Brainstorming merupakan salah satu metode yang dapat mendukung hal tersebut. Metode Brainstorming merupakan suatu metode dimana sekelompok manusia dalam waktu yang singkat mendapatkan banyak ide atau gagasan (Roestiyah, 2001). Brainstorming melibatkan setiap peserta didik untuk menghasilkan ide-ide baru di depan orang lain (Zhao \& Hou, 2010). Dengan menggunakan metode Brainstorming peserta didik dapat dengan leluasa mengeluarkan ide ataupun gagasan tentang materi atau masalah yang sedang dipelajari, hal tersebut dapat mendorong peserta didik untuk lebih aktif dalam mengeluarkan pendapat dari hasil pemikirannya sendiri sehingga dapat meningkatkan kemampuan berpikir kritis peserta didik. Berdasarkan uraian di atas maka peneliti melakukan penelitian mengenai keefektifan model Discovery Learning dengan Brainstorming terhadap kemampuan berpikir kritis peserta didik SMA.

\section{METODE}

Jenis penelitian ini adalah penelitian kuantitatif deskriptif dengan metode quasi-eksperimen. Pada quasi-eksperimen peneliti tidak dapat membentuk kelompok secara artifisial untuk melaksanakan eksperimennya, sehingga dalam penelitian ini menggunakan kelompok utuh atau kelompok kelas yang telah tersedia. Desain penelitian yang digunakan pada adalah Nonequivalent pretest-posttest control group design (gambar 1) dengan group eksperimen dan grup kontrol. Pada penelitian ini peneliti memberikan perlakuan eksperimen dan kontrol pada kelompok-kelompok utuh, memberikan pretest pada kedua kelompok dan melaksanakan kegiatan perlakuan kemudian memberikan postest untuk mengakses perbedaan diantara kedua kelompok (Creswell, 2015). Kelas eksperimen adalah kelas yang di beri perlakuan menggunakan model Discovery Learning dengan Brainstorming, sedangkan kelas kontrol adalah kelas yang diberikan perlakuan dengan pendekatan saintifik 5M. Populasi dalam penelitian ini adalah seluruh peserta didik kelas XI MIPA SMA Negeri 2 Banguntapan tahun ajaran 2018/2019. Sampel yang digunakan pada penelitian ini adalah peserta didik dengan jumlah 32 untuk kelas eksperimen dan peserta dengan jumlah 32 untuk kelas kontrol yang diambil dengan menggunakan teknik cluster random sampling. Kelas yang terpilih sebagai kelas eksperimen adalah kelas XI MIPA 2, sedangkan kelas yang terpilih sebagai kelas kontrol adalah kelas XI MIPA 4.

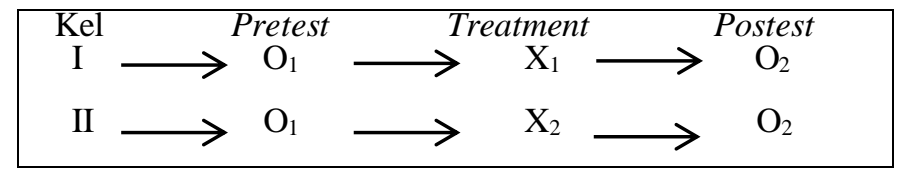

\section{Gambar 1. Desain Penelitian Non-Equivalent Pretest-Posttest Control Group Design}
Kel $=$ Kelompok
I $=$ Kelas eksperimen
II = Kelas kontrol
$\mathrm{O}_{1}=$ Pretest
$\mathrm{O}_{2}=$ Posttest

\author{
$\mathrm{X}_{1}=$ Perlakuan model Discovery Learning \\ dengan Brainstorming \\ $\mathrm{X}_{2}=$ Perlakuan dengan pendekatan 5M.
}


Instrumen yang digunakan dalam penelitian ini adalah instrumen tes berupa 12 soal pretest dan postest berbentuk uraian untuk mendapatkan data kemampuan berpikir kritis. Instrumen yang digunakan telah melalui validasi oleh dosen ahli (expert judgement) dan validasi empiris. Data kuantitatif berupa data kemampuan berpikir kritis yaitu nilai pretest, postest, dan $\mathrm{N}$-gain. Perhitungan $\mathrm{N}$-gain dilakukan untuk mengetahui peningkatan kemampuan berpikir kritis peserta didik. Menurut Hake (1999), N-gain dihitung dengan rumus dan hasil perhitungan kemudian diinterpretasikan dengan menggunakan klasifikasi sebagai berikut:

$$
<g \geq \frac{\text { Skor postest }- \text { Skor pretest }}{\text { Skor Ideal (100)-Skor pretest }}
$$

Tabel 1. Kriteria N-gain

\begin{tabular}{cc}
\hline Batasan N-gain & Interpretasi \\
\hline $\mathrm{N}-$ Gain $\geq 0,7$ & Tinggi \\
\hline $0,3 \leq \mathrm{N}-$ Gain $<0,7$ & Sedang \\
\hline $\mathrm{N}-$ Gain $<0,3$ & Rendah \\
\hline
\end{tabular}

Berdasarkan tabel 1 diatas, jika nilai N-gain kemampuan berpikir kritis peserta didik lebih besar atau sama dengan 0,7 maka terdapat peningkatan kemampuan berpikir kritis dengan kategori tinggi. Apabila data kemampuan berpikir kritis memiliki nilai $\mathrm{N}$-gain di antara 0,3 dan 0,7 maka peningkatan kemampuan berpikir kritis peserta didik pada kategori sedang. Jika nilai $\mathrm{N}$ gain kemampuan berpikir kritis peserta didik lebih kecil dari 0,3 maka peningkatan kemampuan berpikir kritis peserta didik dalam kategori rendah.

Selanjutnya dilakukan teknik analisis data yang meliputi uji prasyarat analisis dan uji hipotesis dengan bantuan SPSS versi 17,0 for windows. Uji prasyarat yang dilakukan adalah uji normalitas dan uji homogenitas dengan bantuan SPSS versi 17,0 for windows dengan taraf signifikan 5\%. Uji normalitas dilakukan untuk mengetahui apakah suatu data berdistribusi normal atau tidak. Uji homogenitas dilakukan untuk mengetahui apakah varian data dari kedua kelompok data homogen atau tidak. Jika data yang diperoleh berdistribusi normal dan memiliki variansi yang homogen, maka dilanjutkan dengan melakukan pengujian hipotesis menggunakan uji independent t-test dengan bantuan SPSS versi 17,0 for windows. Uji independent t-test dilakukan untuk mengetahui apakah ada perbedaan rata-rata nilai posttest kemampuan berpikir kritis peserta didik pada kelas eksperimen yang diberikan perlakuan dengan menggunakan model Discovery Learning dengan Brainstorming dan kelas control yang menggunakan pendekatan saintifik 5M.

\section{HASIL}

Data yang diperoleh dari hasil penelitian ini adalah data pretest dan posttest kemampuan berpikir kritis peserta didik. Data tersebut didapatkan dari hasil tes kemampuan berpikir kritis peserta didik yang pengumpulan datanya menggunakan instrument berupa soal uraian. Berdasarkan hasil analisis deskriptif nilai rata-rata kemampuan berpikir kritis peserta didik kelas eksperimen (Discovery Learning dengan Brainstorming) dan kelas kontrol (pendekatan saintifik 5M) disajikan pada tabel 2.

Tabel 2. Deskripsi Hasil Analisis Data Kemampuan Berpikir Kritis Kelas Eksperimen dan Kelas Kontrol

\begin{tabular}{ccccc}
\hline \multirow{2}{*}{ Deskripsi } & \multicolumn{4}{c}{ Kelas } \\
\cline { 2 - 5 } & \multicolumn{2}{c}{ Eksperimen } & \multicolumn{2}{c}{ Kontrol } \\
\cline { 2 - 5 } & Pretest & Posttest & Pretest & Posttest \\
\hline Rata-rata & 50,65 & 76,43 & 53,45 & 67,25 \\
\hline Simpangan Baku & 7,18 & 12,88 & 7,11 & 8,33 \\
\hline Nilai Minimal & 37,50 & 45,83 & 37,50 & 45,83 \\
\hline Nilai Maksimal & 64,58 & 97,92 & 66,67 & 89,58 \\
\hline
\end{tabular}

Berdasarkan data yang disajikan pada tabel 2, diketahui bahwa rata-rata nilai pretest kemampuan berpikir kritis kelas eksperimen adalah sebesar 50,65 dan rata-rata nilai pretest kemampuan berpikir kritis pada kelas kontrol sebesar 53,45. Hal tersebut menunjukkan bahwa nilai rata-rata pretest kemampuan berpikir kritis peserta didik kelas eksperimen dan kelas kontrol tidak berbeda nyata yang artinya kedua kelas baik eksperimen maupun kontrol memiliki kemampuan berpikir kritis yang hampir sama sebelum diberi perlakuan. Kemudian setelah diberi perlakuan yang berbeda yaitu kelas eksperimen menggunakan model Discovery Learning dengan Brainstorming dan kelas kontrol menggunakan pendekatan saintifik 5M rata-rata nilai posttest kemampuan berpikir kritis 76,43 untuk kelas eksperimen dan 67,25 untuk kelas kontrol yang menandakan rata-rata nilai kemampuan berpikir kritis kedua kelas yaitu kelas eksperimen dan kelas kontrol berbeda nyata. 
Untuk menjawab hipotesis pada penelitian ini maka perlu dilakukan uji hipotesis yaitu dengan uji independent t-test. Sebelum melakukan uji hipotesis, maka perlu dilakukan uji prasyarat terlebih dahulu yaitu dengan melakukan uji normalitas dan uji homogenitas untuk melihat apakah data berdistribusi normal dan homogen. Hasil uji normalitas pada data pretest dan postest kemampuan berpikir kritis peserta didik terangkum pada tabel 3.

Tabel 3. Hasil Uji Normalitas Data Kemampuan Berpikir Kritis

\begin{tabular}{ccccc}
\hline \multirow{2}{*}{ Intervensi } & \multicolumn{3}{c}{ Kolmogorov-Smirnov } \\
\cline { 3 - 5 } & & Statistic & Df & Sig. \\
\hline \multirow{2}{*}{ Pretest } & Kelas Eksperimen & 0,126 & 32 & 0,200 \\
\cline { 2 - 5 } & Kelas Kontrol & 0,097 & 32 & 0,200 \\
\hline \multirow{2}{*}{ Posttest } & Kelas Eksperimen & 0,145 & 32 & 0,085 \\
\cline { 2 - 5 } & Kelas Kontrol & 0,066 & 32 & 0,200 \\
\hline
\end{tabular}

Berdasarkan uji normalitas pada tabel 3 dapat dilihat bahwa nilai signifikansi data pretest pada kelas eksperimen dan kelas kontrol sebesar 0,200. Kemudian nilai signifikansi data posttest kelas eksperimen sebesar 0,085 dan 0,200 untuk data posttest kelas kontrol. Dari hasil uji normalitas yang telah dilakukan di dapatkan nilai signifikansi yang lebih besar dari nilai $\alpha$ $(0,005)$ sehingga data berdistribusi normal. Setelah melakukan uji normalitas dilanjutkan dengan uji homogenitas untuk melihat apakah data pada kedua sampel homogen atau tidak. Hasil dari uji homogenitas dapat dilihat pada tabel 4.

Tabel 4. Hasil Uji Homogenitas Data Kemampuan Berpikir Kritis

\begin{tabular}{lcccc}
\hline & Levene Statistic & df1 & df2 & Sig. \\
\hline Pretest & 0,022 & 1 & 62 & 0,882 \\
\hline Posttest & 3,617 & 1 & 62 & 0,062 \\
\hline
\end{tabular}

Berdasarkan hasil uji homogenitas pada tabel 4, diketahui bahwa nilai signifikansi data pretest dan posttest kelas kontrol dan kelas eksperimen masing-masing 0,882 dan 0,062 yang mana lebih besar dari nilai $\alpha(0,005)$, sehingga data pretest dan posttest kelas eksperimen dan kelas control bersifat homogen.

Setelah didapatkan hasil bahwa data pretest dan postest baik pada kelas eksperimen dan kelas control berdistribusi normal dan homogen maka dilanjutkan dengan uji hipotesis menggunakan uji independet $t$-test. Uji independent $t$-test dilakukan untuk mengetahui apakah ada perbedaan rata-rata nilai posttest kemampuan berpikir kritis peserta didik pada kelas eksperimen yang diberikan perlakuan dengan menggunakan model Discovery Learning dengan Brainstorming dan kelas kontrol yang menggunakan pendekatan saintifik 5M. Rangkuman hasil uji independent t-test kemampuan berpikir kritis termuat pada tabel 5.

Tabel 5. Hasil Uji Independent t-test Data Kemampuan Berpikir Kritis

\begin{tabular}{ccccc}
\hline Jenis Data & Sig. (2-tailed) & $\boldsymbol{\alpha}$ & Keputusan & Keterangan \\
\hline Posttest & 0,001 & 0,05 & Ha diterima & Ada perbedaan signifikan \\
\hline
\end{tabular}

Dari hasil uji Independent t-test kemampuan berpikir kritis pada tabel di atas dapat diketahui bahwa nilai signifikansi data posttest kemampuan berpikir kritis sebesar 0,001. Nilai signifikansi 0,001 lebih kecil dari nilai $\alpha(0,05)$, yang menunjukkan bahwa terdapat perbedaan yang signifikan antara rata-rata nilai kelas ekskperimen yang diberikan perlakuan dengan menggunakan model Discovery Learning dengan Brainstorming dan kelas kontrol yang menggunakan pendekatan saintifik 5M. Selanjutnya, perlu diketahui nilai $N$-gain untuk mengetahui peningkatan kemampuan berpikir kritis pada kelas eksperimen dan kelas kontrol setelah diberikan perlakuan. Data hasil N-gain dapat dilihat pada tabel 6.

Tabel 6. Hasil Analisis Data $N$-gain Kelas Eksperimen dan Kelas Kontrol

\begin{tabular}{ccccc}
\hline Kelas & Pretest & Postest & $\boldsymbol{N}$-gain & Kriteria \\
\hline Eksperimen & 50,65 & 76,43 & 0,53 & Sedang \\
\hline Kontrol & 53,45 & 67,25 & 0,30 & Rendah \\
\hline
\end{tabular}

Dari tabel 6 dapat dilihat bahwa terjadi peningkatan kemampuan berpikir kritis peserta didik pada kelas eksperimnen dan kontrol. Hal tersebut dapat dilihat dari hasil nilai $N$-gain pada kelas eksperimen sebesar 0,53 dengan kategori sedang dan kelas kontrol sebesar 0,30 dengan kategori rendah. Untuk lebih jelas dapat dilihat pada gambar 2. 


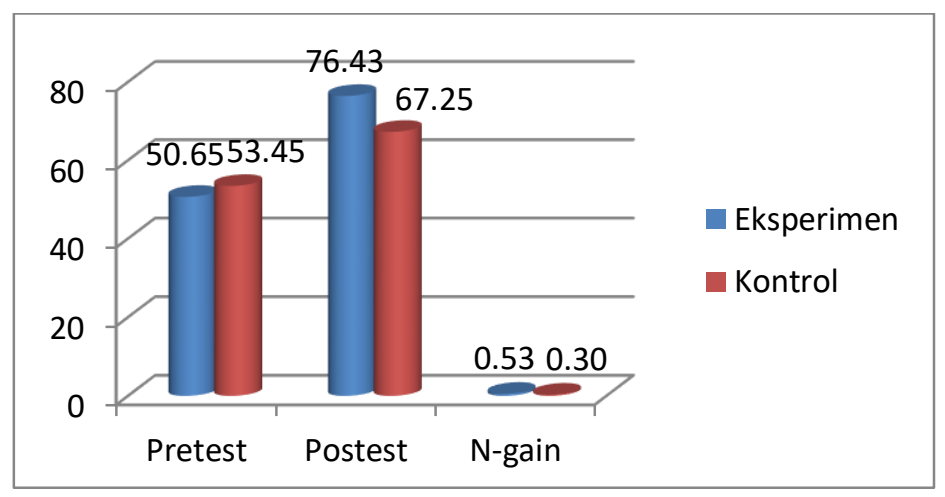

Gambar 2. Diagram Pretest, Posttest, dan N-Gain Kelas Eksperimen dan Kelas Kontrol

Berdasarkan gambar 2, dapat dilihat dengan jelas bahwa jika dibandingkan, nilai $\mathrm{N}$-gain antara kelas eksperimen dan kelas kontrol hasilnya lebih tinggi pada kelas eksperimen. Diketahui dengan rata-rata nilai pretest yang sebelumnya 50,65 menjadi 76,43 pada posttest dengan nilai $N$-gain sebesar 0,53 , sedangkan pada kelas kontrol nilai pretest yang sebelumnya 53,45 menjadi 67,25 pada posttest dengan nilai $\mathrm{N}$-gain sebesar 0,30 . Hal tersebut menunjukkan terjadinya peningkatan kemampuan berpikir kritis yang lebih tinggi pada kelas eksperimen. Data hasil nilai $N$-gain juga menunjukkan bahwa model Discovery Learning dengan Brainstorming yang diterapkan pada kelas eksperimen memiliki efektivitas yang lebih baik jika dibandingkan kelas kontrol yang menggunakan pendekatan saintifik 5M.

\section{PEMBAHASAN}

Pembelajaran menggunakan model Discovery Learning dengan Brainstorming terbukti efektif terhadap kemampuan berpikir kritis peserta didik. Penggunaan model Discovery Learning dengan Brainstorming dalam pembelajaran dapat membuat peserta didik lebih aktif dalam menemukan sendiri materi yang diajarkan. Hal tersebut terjadi karena dalam pembelajaran menggunakan model Discovery Learning dengan Brainstorming peserta didik dihadapkan pada kegiatan penemuan melalui pengamatan dan pengkajian literatur yang mengharuskan mereka untuk menyelesaikannya bersama teman kelompoknya. Peserta didik juga diberikan kesempatan untuk mengeluarkan gagasan atau ide yang mereka miliki sebanyak-banyaknya tentang masalah atau materi yang sedang dipelajari sehingga membuat kemampuan berpikir kritis peserta didik meningkat. Hal tersebut selaras dengan pendapat Masrida, Hala, \& Taiyeb (2016) yang menyatakan bahwa proses pembelajaran yang memberikan kesempatan bagi peserta didik untuk mengeluarkan pendapatnya dan bertukar informasi saat kegiatan diskusi kelompok tidak hanya dapat meningkatkan pemahaman dalam materi pembelajaran tetapi juga dapat meningkatkan kemampuan berpikir kritis peserta didik.

Berdasarkan hasil analisis data yang telah dilakukan pada penelitian ini juga menunjukkan bahwa penggunakan model Discovery Learning dengan Brainstorming efektif secara signifikan dalam meningkatkan kemampuan berpikir kritis peserta didik. Merujuk pada hasil analisis deskriptif diketahui bahwa nilai rata-rata kelas eksperimen lebih tinggi dibandingkan nilai kelas kontrol setelah diberi perlakuan yaitu sebesar 76,43 untuk kelas eksperimen dan 67,25 untuk kelas kontrol. Berdasarkan uji independent $t$-test, diketahui bahwa nilai signifikansi kemampuan berpikir kritis sebesar $0,001 \leq \alpha(0,05)$ yang menunjukkan terdapat perbedaan yang signifikan antara rata-rata nilai kemampuan berpikir kritis kelas eksperimen dan kelas kontrol. Untuk mengetahui peningkatan kemampuan berpikir kritis setelah diberi perlakuan menggunakan model Discovery Learning dengan Brainstorming, dilakukan perhitungan nilai $\mathrm{N}$-gain. Berdasarkan hasil analisis yang telah dilakukan, didapatkan nilai $\mathrm{N}$-gain kelas eksperimen sebesar 0,53 dengan kategori sedang dan kelas kontrol sebesar 0,30 dengan kategori rendah. Hasil tersebut menunjukkan bahwa penggunaan model Discovery Learning dengan Brainstorming lebih efektif untuk meningkatkan kemampuan berpikir kritis peserta didik.

Hasil dari penelitian ini sesuai dengan hasil penelitian yang telah dilakukan oleh Sapitri, Kurniawan, \& Sulistri (2016) dan Oktaviani, Kristin, \& Anugraheni (2018) yang pada hasil penelitiannya menunjukkan adanya peningkatan kemampuan berpikir kritis yang disebabkan karena model Discovery Learning. Setelah menggunakan model pembelajaran Discovery Learning peserta didik merasa mudah melakukan aspek kemampuan berpikir kritis seperti memberikan argumen, melakukan deduksi dan induksi, serta melakukan evaluasi (Agustina, Achmad, \& Yolida, 2015). Peningkatan kemampuan berpikir kritis peserta didik terjadi karena saat pembelajaran dengan model Discovery Learning guru memberikan kesempatan kepada peserta didik untuk belajar secara aktif, mengembangkan kemampuan analisis dan mengolah informasi yang di dapat (Nugrahaeni, Redhana, \& Kartawan, 2017). Hal ini sesuai dengan dengan pendapat Kinasih, Jalmo, \& Yolida (2015) bahwa adanya keaktifan peserta didik dalam proses pembelajaran menggunakan model Discovery Learning menyebabkan peserta didik melakukan berbagai aktivitas belajar yang dapat melatih kemampuan berpikir kritisnya. Dengan belajar menggunakan model Discovery Learning peserta didik dapat menemukan sendiri pengetahuannya melalui kegiatan pengamatan yang dilakukan secara langsung sehingga kemampuan berpikir kritis peserta didik dapat meningkat. 
Melalui aktivitas pembelajaran menggunakan model Discovery learning dengan brainstorming akan membiasakan peserta didik secara tidak langsung untuk aktif dalam proses pembelajaran serta melatih kemampuan berpikir kritis mereka melalui tahapan-tahapan yang ada pada model Discovery learning dengan brainstorming. Seperti pendapat Kinasih et al., (2015) pada proses pembelajaran menggunakan Discovery Learning terdapat langkah-langkah atau tahapan yang dapat mendukung peserta didik untuk berpikir kritis dalam bidang sains. Pembelajaran menggunakan model discovery learning dapat meningkatkan kemampuan berpikir peserta didik karena mereka dilatih untuk mengamati dan menanya pada tahap stimulation, menanya dan mengumpulkan informasi (tahap problem statement), mencoba dan mengamati (tahap data collection), menalar dan menanya (tahap data processing), menalar (tahap verification), menyimpulkan dan mengomunikasikan (tahap Generalization) (Pratiwi, Hairida, \& Rasmawan, 2014). Seorang pemikir kritis memiliki sifat terbuka pada cara pandang seseorang terhadap suatu masalah, menilai sesuatu dengan alasan yang jelas dan menggunakan penilaian tersebut untuk membuat keputusan tentang apa yang harus dipercaya dan tindakan apa yang harus diambil (Browne \& Keeley, 2018). Hal ini menunjukkan bahwa pada saat pembelajaran menggunakan model Discovery learning dengan brainstorming peserta didik dapat mengembangkan kemampuan berpikir kritisnya karena dalam pelaksanaan pembelajarannya peserta didik didorong untuk saling terbuka dalam menerima pendapat orang lain saat kegiatan diskusi, peserta didik juga didorong untuk melakukan penilaian terhadap data yang diperolah dengan alasan yang jelas dan membuat keputusan berupa kesimpulan tentang data yang telah diperoleh saat melakukan kegiatan percobaan atau penyelidikan. Hal ini didukung oleh hasil penelitian Aizikovitsh-Udi \& Cheng (2015), bahwa kemampuan berpikir kritis dapat dikembangkan jika seorang guru secara konsisten dan sistematis mendorong peserta didik untuk berpikir kritis di kelas mereka dengan merencanakan pelajaran investigasi atau penyelidikan serta kegiatan debat atau diskusi.

Metode Brainstorming juga turut berperan dalam meningkatnya kemampuan berpikir kritis peserta didik. Dengan metode Brainstorming peserta didik dapat menuangkan semua gagasan, pendapat, dan pengetahuannya dalam proses pembelajaran yang menyebabkan kemampuan berpikir kritis peserta didik meningkat. Hal ini sejalan dengan hasil penelitian dari Aldeirre, Komala, \& Heryanti (2018) dan Damayanti, Pudjawan, \& Surjana (2016) bahwa metode Brainstorming berpengaruh terhadap kemampuan berpikir kritis. Melalui kegiatan curah pendapat membuat peserta didik berpikir secara kritis dalam menuangkan segala pengetahuannya. Berdasarkan hal tersebut dapat diketahui bahwa penggunaan model pembelajaran Discovery Learning dengan Brainstorming efektif secara signifikan terhadap kemampuan berpikir kritis peserta didik.

\section{SIMPULAN}

Berdasarkan analisis hasil penelitian dan pembahasan dapat disimpulkan bahwa penggunaan model Discovery Learning dengan Brainstorming efektif secara signifikan terhadap kemampuan berpikir kritis peserta didik. hal ini ditunjukkan melalui hasil uji independent $t$-test dan perhitungan nilai $\mathrm{N}$-gain. Hasil uji independent $t$-test dengan nilai signifikansi $0,001 \leq$ 0,05 yang membuktikan adanya perbedaan yang signifikan antara penggunaan model Discovery Learning dengan Brainstorming dan penggunaan pendekatan saintifik 5M terhadap kemampuan berpikir kritis. Hasil perhitungan nilai $\mathrm{N}$-gain pada kelas eksperimen yang menggunakan model Discovery Learning dengan Brainstorming sebesar 0,53 dengan kategori sedang dan kelas kontrol dengan pendekatan saintifik 5M sebesar 0,30 dengan kategori rendah. Hal tersebut menunjukkan terjadinya peningkatan kemampuan berpikir kritis yang lebih tinggi pada kelas eksperimen yang menggunakan model Discovery Learning dengan Brainstorming dibandingkan kelas kontrol yang menggunakan pendekatan saintifik 5M.

\section{DAFTAR RUJUKAN}

Agustina, M., Achmad, A., \& Yolida, B. (2015). Pengaruh Model Discovery Learning terhadap Kemampuan Berpikir Kritis dan Hasil Belajar Siswa. Jurnal Bioterdidik: Wahana Ekspresi Ilmiah, 3(6), 1-9. http://jurnal.fkip.unila.ac.id/index.php/JBT/article/view/9253/5891

Aizikovitsh-Udi, E., \& Cheng, D. (2015). Developing Critical Thinking Skills from Dispositions to Abilities: Mathematics Education from Early Childhood to High School. Creative Education, 06(04), 455-462. https://doi.org/10.4236/ce.2015.64045

Aldeirre, D., Komala, R., \& Heryanti, E. (2018). Pengaruh Metode Pembelajaran Brainstorming terhadap Kemampuan Berpikir Kritis Materi Vertebrata pada Siswa SMA. Jurnal Biologi dan Pembelajarannya, 5(2), 110-116. http://doi.org/10.25273/florea.v5i2.3451

Amri, S., \& Ahmadi, K. I. (2010). Proses Pembelajaran Inovatif dan Kreatif dalam Kelas. Jakarta: Prestasi Pustakarya.

Balım, A. G. (2009). The Effects of Discovery Learning on Students' Success and Inquiry Learning Skills. Egitim Arastirmalari-Eurasian Journal of Educational Research, 35(1), 1-20. https://pdfs.semanticscholar.org/c92b/f85fbf5545de25f1724f22f948436f107d80.pdf

Ballew, H. (1967). Discovery Learning and Critical Thinking in Algebra. The High School Journal, 50(5), 261-270. https://www.jstor.org/stable/40365965

Browne, M. N., \& Keeley, S. M. (2018). Asking the Right Questions:A Guide to Critical Thinking. United States of America: Pearson Prentice Education.

Bruner, J. S. (1997). On Knowing Essays for The Left Hand. United States of Amerika: University Press. 
Chukwuyenum, A. N. (2013). Impact of Critical Thinking on Performance in Mathematics among Senior Secondary School Students in Lagos State. IOSR Journal of Research \& Method in Education (IOSR-JRME), 3(5), 18-25. http://www.iosrjournals.org/iosr-jrme/papers/Vol-3 Issue-5/D0 351825.pdf

Creswell, J. (2015). Riset Pendidikan:Perencanaan, Pelaksanaan, dan Evaluasi Riset Kualitatif \& Kuantitatif. Yogyakarta: Pustaka Pelajar.

Damayanti, N. P. A. P., Pudjawan, K., \& Surjana, I. M. (2016). Pengaruh Metode Pembelajaran Brainstorming Terhadap Kemamampuan Berpikir Kritis Siswa Mata Pelajaran IPA Kelas V SD. Mimbar PGSD Universitas Pendidikan Ganesha, 4(1), 1-10.

De Jong, T., \& Van Joolingen, W. R. (1998). Discovery Learning with Computer Simulations of Conceptual Domains. Review of Educational Research, 68(2), 179-201. https://doi.org/10.3102/00346543068002179

Duron, R., Limbach, B., \& Waugh, W. (2006). Critical Thinking Framework for Any Discipline. International Journal of Teaching and Learning in Higher Education, 17(2), 160-166. http://doi.org/10.1016/j.nepr.2006.09.004

Hosnan, M. (2014). Pendekatan Saintifik dan Kontekstual dalam Pembelajaran Abad 21. Jakarta: Ghalia Indonesia.

Kinasih, M. E., Jalmo, T., \& Yolida, B. (2015). Pengaruh Model Discovery Learning terhadap Keterampilan Berpikir Kritis Siswa. Jurnal Bioterdidik: Wahana Ekspresi Ilmiah, 30(10), 50-60.

Martaida, T., Bukit, N., \& Ginting, E. M. (2017b). The Effect of Discovery Learning Model on Student's Critical Thinking and Cognitive Ability in Junior High School. IOSR Journal of Research \& Method in Education (IOSR-JRME), 7(6), 01-08. https://doi.org/10.9790/7388-0706010108

Masrida, Hala, Y., \& Taiyeb, A. M. (2016). Pengaruh Model Pembelajaran Discovery terhadap Keterampilan Berpikir Kritis dan Hasil Belajar IPA Kelas VIII MTSN Libureng Kabupaten Bone. Jurnal Bionature, 17(2), 81-87.

Njoo, M. K. H. (1994). Exploratory Learning with a Computer Simulation: Learning Processes and Instructional Support. Eindhoven: Technische Universiteit Eindhoven.

Nugrahaeni, A., Redhana, I. W., \& Kartawan, I. M. A. (2017). Penerapan Model Pembelajaran Discovery Learning untuk Meningkatkan Kemampuan Berpikir Kritis dan Hasil Belajar Kimia. Jurnal Pendidikan Kimia Indonesia, 1(1), $23-29$. http://dx.doi.org/10.23887/jpk.v1i1.12808

Oktaviani, W., Kristin, F., \& Anugraheni, I. (2018). Penerapan Model Pembelajaran Discovery Learning untuk Meningkatkan Kemampuan Berpikir Kritis dan Hasil Belajar Matematika Siswa Kelas 5 S. Jurnal Basicedu: Research \& Learning in Elementary Education, 2(2), 5-10. https://doi.org/10.31004/basicedu.v2i2.41

Pertiwi, I. S., Marpaung, R. R. T., \& Yolida, B. (2015). Pengaruh Penggunaan Model Discovery Learning terhadap Kemampuan Berpikir Kritis. Jurnal Bioterdidik:Wahana Ekspresi Ilmiah, 3(8), 98-106. http://jurnal.fkip.unila.ac.id/index.php/JBT/article/view/9711

Pratiwi, F. A., Hairida, \& Rasmawan, R. (2014). Pengaruh Penggunaan Model Discovery Learning dengan Pendekatan Saintifik terhadap Keterampilan Berpikir Kritis Siswa SMA. Jurnal Pendidikan dan Pembelajaran, 3(7), 1-16. https://doi.org/https://doi.org/10.1021/je020007r

Roestiyah, N. K. (2001). Strategi Belajar Mengajar (Salah Satu Unsur Pelaksanaan Strategi Belajar Mengajar: Teknik Penyajian). Jakarta: Rineka Cipta.

Sapitri, U. M., Kurniawan, Y., \& Sulistri, E. (2016). Penerapan Model Discovery Learning untuk Meningkatkan Keterampilan Berpikir Kritis Siswa Kelas X pada Materi Kalor. Jurnal Ilmu Pendidikan Fisika, 1(2), 64-66. http://dx.doi.org/10.26737/jipf.v1i2.66

Zetriuslita, Ariawan, R., \& Nufus, H. (2016). Students' Critical Thinking Ability: Description Based on Academic Level and Gender. Journal of Education and Practice, 7(12), 154-164.

Zhao, Z., \& Hou, J. (2010). The Study on Influencing Factors of Team Brainstorming Effectiveness. International Journal of Bussiness and Management, 5(1), 181-184. 